Marquette University

e-Publications@Marquette

Mechanical Engineering Faculty Research and

Publications

Mechanical Engineering, Department of

$9-2003$

\title{
Business Case for Implementing Two Ergonomic Interventions at an Electric Power Utility
}

Patricia Seeley

Ergonomics Solutions

Richard W. Marklin

Marquette University, richard.marklin@marquette.edu

Follow this and additional works at: https://epublications.marquette.edu/mechengin_fac

Part of the Mechanical Engineering Commons

\section{Recommended Citation}

Seeley, Patricia and Marklin, Richard W., "Business Case for Implementing Two Ergonomic Interventions at an Electric Power Utility" (2003). Mechanical Engineering Faculty Research and Publications. 37.

https://epublications.marquette.edu/mechengin_fac/37 
Marquette University

e-Publications@Marquette

\section{Mechanical Engineering Faculty Research and Publications/College of Engineering}

This paper is NOT THE PUBLISHED VERSION; but the author's final, peer-reviewed manuscript. The published version may be accessed by following the link in the citation below.

Pplied Ergonomics, Vol. 34, No. 5 (September 2003): 429-439. DOI. This article is (C) Elsevier and permission has been granted for this version to appear in e-Publications@Marquette. Elsevier does not grant permission for this article to be further copied/distributed or hosted elsewhere without the express permission from Elsevier.

\section{Business Case for Implementing Two Ergonomic Interventions at An Electric Power Utility}

Patricia A. Seeley

We Energies, 2425 S. 35th Street, Mail Code SSC2, Milwaukee, WI Richard W. Marklin

Department of Mechanical and Industrial Engineering, Marquette University, P.O. Box 1881, Milwaukee, WI

\footnotetext{
Abstract

Ergonomics analysis of line workers in the electric power industry who work overhead on utility poles revealed some tasks for which less than $1 \%$ of the general population had sufficient strength to perform. During a 2-year study, a large Midwestern US electric utility provided a university with a team of represented workers and management. They evaluated, recommended, and monitored interventions for 32 common line worker tasks
} 
that were rated at medium to high magnitude of risk factors for musculoskeletal disorders (MSDs). Two of the recommended ergonomic interventions - the battery-operated press and cutter-were selected by the team as having the greatest potential for reducing risk factors of MSDs. Only overhead distribution line worker tasks were evaluated. A business case was formulated that took into account medical injury and illness statistics, workers' compensation, replacement worker and retraining costs. An outline of a business case formulation and a sample intervention payback calculation is shown. Based on the business case, the utility committed over $\$ 300,000$ to purchase battery-operated presses and cutters for their overhead distribution line crews.

\section{Keywords}

Ergonomics, Business case, Electric power utility

\section{Introduction}

Corporate management does not always believe that there is a benefit from ergonomic interventions because of the difficulty of making clear cause-effect connections between tools or work practices and actual or potential injuries. The medical and workers' compensation costs are often hidden by workers who take sick days but do not report injuries to the company. Once the leap is made from medical only costs into "benefits" expensewhich includes "lost wages, medical expenses, disability, and medical and vocational rehabilitation -the case is even stronger (Rodrigues, 2001)." Actual numerical value of costs and benefits can aid ergonomists in developing a business case for ergonomic interventions.

Before presenting a cost justification for a specific ergonomic intervention, an ergonomics analysis of the occupational risk factors of musculoskeletal disorders (MSDs) inherent in the respective task, such as low back pain and carpal tunnel syndrome, was necessary. In this study, the Electric Power Research Institute (EPRI) provided funding to a local university, which worked closely with a large Midwestern electric utility in the US, to investigate 32 common line worker tasks, identify and quantify MSD risk factors, and generate and implement ergonomic interventions. The line worker tasks evaluated in this study were overhead distribution and did not include any underground tasks. The large Midwestern electric utility-hereafter called the "utility" - assembled an ergonomics team, which consisted of eight line workers, two supervisors, an applications engineer, an occupational health nurse, and two health and safety professionals. Site visits to other electric utilities in the US also were conducted to assure the tasks under investigation were common throughout the US (EPRI, 2001).

The vision in this study that ergonomics could make a significant positive impact on the working lives of line workers and those who work at other physically demanding jobs needs to be marketed. By reducing the incidence and severity of injuries resulting in restricted duty (RD) or lost work days (LWDs), the overall occupational health of line workers will improve, thereby enhancing their quality of life and reducing costs to the employer. Prevention of injuries is far more cost-effective than sending people back to work for repeated reinjury, but is often hard to explain and forecast.

One way to make the case for ergonomics is to sell efficient energy delivery-including all forms of customer service-as the goal, as opposed to injuries or illnesses that can be viewed as inefficiencies (Slavin, 2001). Such an approach keeps the emphasis on benefits, instead of costs. Many of the 32 recommended ergonomic interventions from this study also save time, from minutes per task to hours; thus, labor savings should be factored into cost justifications.

One of the hurdles in selling ergonomics to management is that they see it as high cost, low value. An effective way to sell ergonomics in a company is to implement a few simple success stories of the opposite type, low cost-high value. The positive benefits of these ergonomic interventions then should be communicated widely 
across the company, and awareness of ergonomics can be promoted by training various levels of workers and management.

Nineteen of the 32 tasks investigated by the ergonomics team at the utility were in the category of low costhigh value. However, two of the 32 interventions that the team believed would improve the occupational health of line workers the most-the battery-operated press and the battery-operated cutter-required initial investment of a substantial nature. The business case for the battery-operated press and cutter is provided in this article as a model for safety and health professionals in the electric utility industry.

\section{Method}

\subsection{Data review}

The following data from the utility during the January 1999-July 2001 period were reviewed:

- Medical and workers' compensation costs for 47 cases of MSDs that resulted in time off work, either LWDs or RD days.

- The total number of MSDs ( $n=167)$ experienced by all the line workers $(n=370)$ at the utility which included those MSDs that did not result in lost or RD days. However, the total costs for all these injuries were not accessible because some workers were treated by their private physicians or the cost data were not available from the company that managed the workers' compensation cases for the utility. Examples of these MSDs such as muscle strains and tendinitis were believed by the corporate ergonomist to be caused by cumulative exposures. Acute or traumatic injuries such as sprained wrists or ankles, lacerations, contusions, slips and falls were not included in the 167 cases.

-Training and productivity costs for apprentice line workers to become permanent replacements for skilled line workers.

- Personnel records for line workers leaving their jobs.

-Personnel information on hourly wages and benefits for various line worker job classifications.

- Replacement worker costs for skilled line workers who could not perform their jobs due to temporary RD, permanent partial disability, or LWDs for injury recovery, surgery, or rehabilitation.

\subsection{Cost of worker injuries}

Many costs stem from workers' injuries, which may include (Ergonomics That Work, 1998):

- Permanent partial or total disability costs.

- Lost time (hourly rate multiplied by number of hours missed per occurrence).

- Medical costs: doctors, tests, hospital, physical therapy, chiropractic care, company medical evaluations.

- Time spent discussing the injury or illness with workers, supervisors, health care professionals.

- Sick days' costs for injuries not reported as work-related.

- Case investigation.

- Clerical time handling claims.

- Operational downtime due to discussion of injury.

Each utility needs to gather as much relevant data that is accessible in order to make a business case for ergonomic interventions. 


\subsection{Cost of replacement workers}

The cost of replacing workers is not trivial; 12 weeks of training are invested in new line worker apprentices at the utility besides on the job training. Some candidates dropout during the initial phase of the training process, decreasing in number as the process progresses. The total investment for training an apprentice at the utility amounted to $\$ 13,000$ per apprentice for the 3 years of training and job simulation, resulting in a retraining cost of $\$ 4333$ per year (for 3 years) to replace each skilled line worker who leaves the profession. The utility hires approximately $30-40$ new apprentices per year, who replace about $10 \%$ of the line worker population yearly, and only $10 \%$ of the apprentices replace retirees. Most of the remainder of line workers, $90 \%$, left their jobs for supervisory roles within the utility or left the company. Many non-retirement line workers who left their jobs did so primarily for occupational health reasons. Some of the factors involved in replacing skilled workers permanently or temporarily are the following (Ergonomics That Work, 1998):

- Less output of the injured worker when they return to work from RD or LWDs.

-Employee replacement and training overtime for substitutes or additional manpower.

-Education investment in lost person.

-Reduced productivity of replacement workers.

\subsection{Selection of business case model}

\subsubsection{Simplified model}

Boff and Rouse (1997) provided a simplified model for making the business case for ergonomic interventions. This model included the following steps:

- Identify stakeholders.

- Define benefits and costs.

-Weigh and estimate benefits and costs for different stakeholders.

- Forecast levels of benefits and costs.

-Evaluate alternative work practices.

The reason for the simplified model-rather than the use of the many computational models availablewas Boff and Rouse's (1997) recognition that, in the ergonomics and human factors arena, much of the traditional return on investment (ROI) data were simply not available. They pared the process down to one that most business professionals can understand with data that can be accessed through conventional means.

The key word in Boff and Rouse's (1997) model was 'stakeholders': those who make the decisions on tooling, work practices, or capital expenditures. Two groups of stakeholders at the utility are the tool committee and the business unit safety team. Another stakeholder was the vice-president, who was and continues to be very supportive at the utility, providing ergonomics team members substantial time away from their regular jobs for their ergonomics work during and after the 2 year duration of the study.

\subsubsection{Business case format}

The criteria for cost justification of large capital expenditures were provided by the utility's financial department. These criteria consisted of the following:

- project overview,

-project proposal,

- project benefits,

-alternatives considered, 
- cost breakdown,

- cost authorization needed (capitalization over 5-year period),

- simplified cost/benefit table,

- product type,

- annual benefit,

- estimated total cost,

- payback in years,

-request for approval,

-summary of request.

\subsection{Presentation of the business case}

\subsubsection{Project overview}

\subsubsection{Selection of the two tools}

In a musculoskeletal survey of 152 active line workers from three US electric power utilities (one Midwestern, one Southeastern, and one Southwestern), 99 respondents indicated severe symptoms of MSDs from the use of two tools, the manual compression press and an assortment of wire cutting tools (EPRI, 2001). They indicated chronic pain to elbows, shoulders, backs, and other body parts. In fact, anthropometric analysis indicated that less than $1 \%$ of the general population were capable of crimping a common pair of wires with the manual compression press (EPRI, 2001).

\subsubsection{Manual compression press vs. battery-operated press}

Compression connections were made with a manual compression press that weighed approximately $3 \mathrm{~kg}$ and had handles that were approximately $64 \mathrm{~cm}$ long. Fig. 1 shows a typical manual compression press. When the handles were completely open, the span between the ends of the handles was $96 \mathrm{~cm}$. The connector was placed on two wires, and the head of the manual compression tool was placed on the connector. As illustrated in Fig. 2, the line worker pulled the handles together, crimping the connector onto the wires.

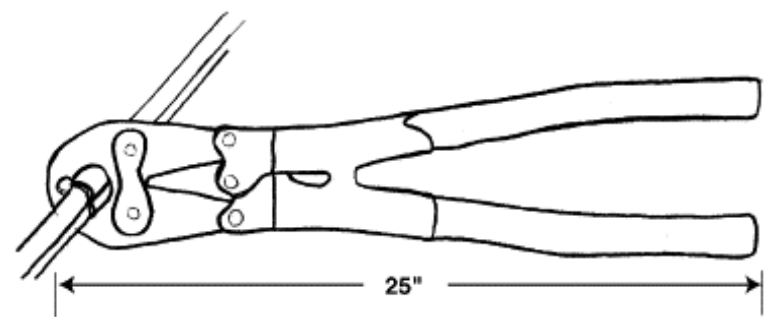

Fig. 1. A compression connector crimped with a manual compression press (EPRI, 2001). 


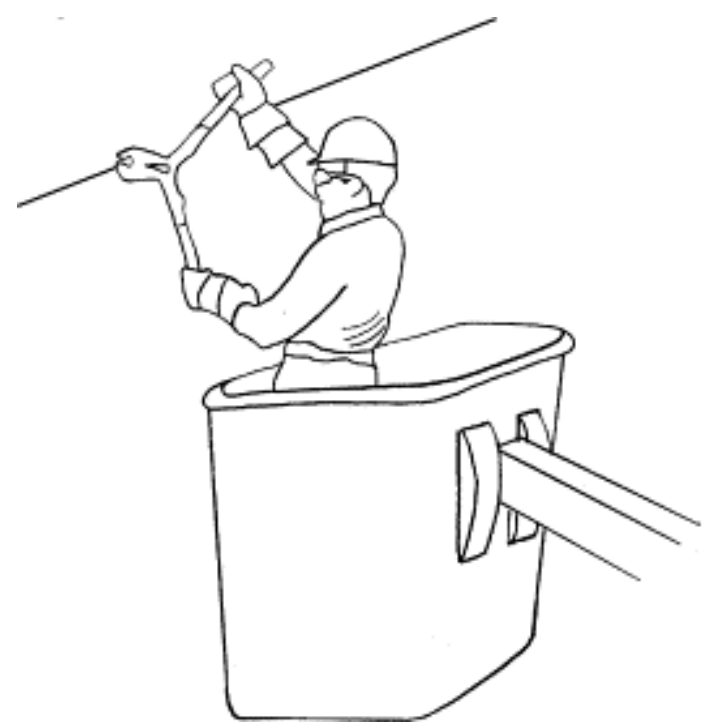

Fig. 2. A line worker crimping a compression connector with a manual compression press from a bucket (EPRI, 2001).

The battery-operated press was approximately $4.5 \mathrm{~kg}, 33 \mathrm{~cm}$ long and $30 \mathrm{~cm}$ tall. As shown in Fig. 3, the head of a battery-operated press opened and fit over the two wires and the connector, in the same manner as a manual compression press. A trigger on the battery-operated press was depressed and held until the connector was fully compressed. The process was repeated until the requisite number of crimps were made on a connector, usually 4-5 per connector.

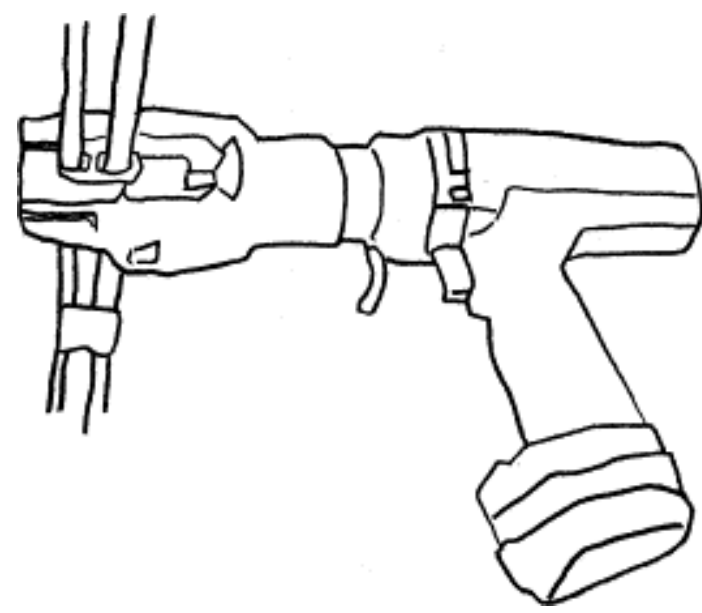

Fig. 3. A compression connector crimped with a battery-operated press (EPRI, 2001).

\subsubsection{Manual cutter vs. battery-operated cutter}

Various methods were used to cut wire of size \#2 AWG and larger. Some of the cutting tools used to cut wire were long handled cable sheers ( $51 \mathrm{~cm}$ long and $1.4 \mathrm{~kg}$ ), ratchet cable cutters (48-76 cm long and $2-4.5 \mathrm{~kg}$ ), bolt cutters (49-61 cm long and 1.4-2 kg), and hacksaws. All of these tools, except the hacksaw, were used in a similar way. The line worker placed the head of the cutter onto the wire and then squeezed the handles closed. This motion was repeated several times for the ratchet cutter. Sometimes line workers supported one handle of a manual cutter with their torso or shoulder and pulled the other handle with two hands, as illustrated in Fig. 4. 


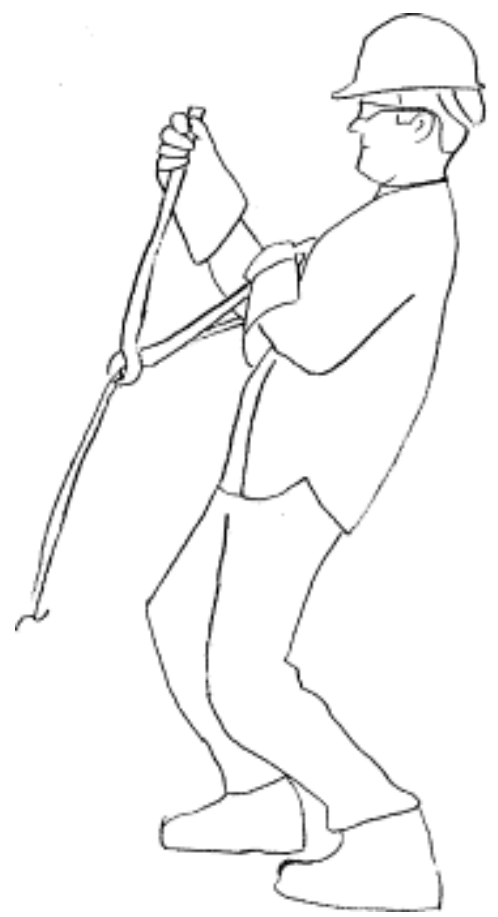

Fig. 4. A line worker cutting a large diameter wire with a manual cutter (EPRI, 2001).

A battery-operated cutter ( $2.3 \mathrm{~kg}$ and $38 \mathrm{~cm}$ long), shown in Fig. 5, was available for cutting wire at least as large as $1000 \mathrm{kcmil}$. The line worker placed the open blade over the wire and pressed the trigger until the wire was cut.

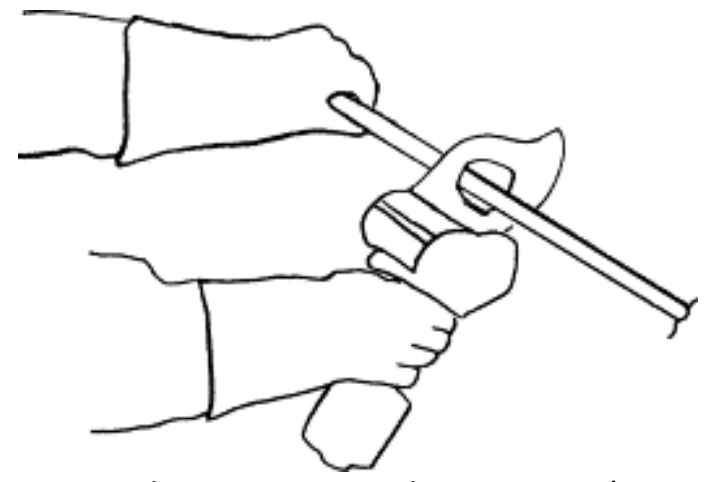

Fig. 5. A battery-operated wire cutter (EPRI, 2001).

\subsubsection{Project proposal}

The investigators of this study believed that that the battery-operated press and cutter would have the most beneficial impact on the occupational health of line workers at the utility. Feedback from line workers at the utility showed that some line workers would probably not use the battery-operated press as a cutting tool because of the extra setup time required to switch heads. Thus, the ergonomics team recommended a separate battery-operated cutter to cut wires in order to maximize usage. Before all crews were outfitted with the presses and cutters, a feasibility pilot study was conducted at the utility. During this pilot study, the team continued their investigation of commercially available battery-operated tools. The team did not find a new battery-operated tool on the market that would be simple to setup for both pressing and cutting and be acceptable to almost all line workers. Thus, separate battery-operated presses and cutters were recommended by the team. 


\subsubsection{Project benefits}

The battery-operated press addressed the risk factors of MSDs listed in Table 1 . The risk factors of the batteryoperated cutter are addressed in Table 2 . By reducing or eliminating risk factors of upper extremity MSDs, it was hypothesized that significant reductions in medical, workers' compensation, replacement workers, and retraining costs will be realized. In addition, the corporate ergonomist at the utility hypothesized that a productivity benefit will be realized by keeping skilled workers longer and healthier in their jobs as well as improving their quality of life. Labor costs for hiring and training new apprentices were also hypothesized to be substantially reduced.

Table 1. Risk factors of MSDs from making compression connections with the manual press and improvements with the battery-operated press

\begin{tabular}{|l|l|l|}
\hline Risk factor & Manual press risks & $\begin{array}{l}\text { Improvement with } \\
\text { battery-operated tool }\end{array}$ \\
\hline $\begin{array}{l}\text { Amount of handle force required to } \\
\text { compress a } 1 / 0-\sharp 2 \text { wire pair is } \\
\text { approximately } 311 \mathrm{~N} \text { at the outer die } \\
\text { location of the manual press }\end{array}$ & $\begin{array}{l}\text { Only 1\% capable of the general } \\
\text { population has the peak force to make } \\
\text { this connection }\end{array}$ & $\begin{array}{l}\text { Nearly all workers } \\
\text { capable }\end{array}$ \\
\hline $\begin{array}{l}\text { High shoulder force exertions working } \\
\text { from a pole }\end{array}$ & $\begin{array}{l}\text { Peak shoulder muscle EMG using the } \\
\text { manual press was over 50\% MVC } \\
\text { (maximal voluntary contraction) }\end{array}$ & $\begin{array}{l}\text { Reduced from over 50\% } \\
\text { MVC to 30\% MVC (40\% } \\
\text { relative reduction) }\end{array}$ \\
\hline $\begin{array}{l}\text { High shoulder force exertions working } \\
\text { from a bucket }\end{array}$ & Peak EMG 45\% MVC & $\begin{array}{l}\text { Reduced to less than 10\% } \\
\text { MVC (over 80\% relative } \\
\text { reduction) }\end{array}$ \\
\hline $\begin{array}{l}\text { Peak forces of flexor muscles in } \\
\text { forearm from working on pole }\end{array}$ & Peak EMG of 90\% MVC & $\begin{array}{l}\text { Peak decreased from 90\% } \\
\text { MVC to 60\% MVC (a 33\% } \\
\text { relative reduction) }\end{array}$ \\
\hline $\begin{array}{l}\text { Peak forces of flexor muscles in } \\
\text { forearm from working in bucket }\end{array}$ & Peak EMG of 100\% MVC & $\begin{array}{l}\text { From 100\% MVC to 60\% } \\
\text { MVC (a 40\% relative } \\
\text { decrease) }\end{array}$ \\
\hline $\begin{array}{l}\text { Jarring action of manual compression } \\
\text { tool }\end{array}$ & Not measured, but substantial & $\begin{array}{l}\text { Eliminated 100\%; } \\
\text { virtually all workers } \\
\text { capable }\end{array}$ \\
\hline Twisted and awkward trunk postures & & $\begin{array}{l}\text { Improved posture from } \\
\text { the bucket }\end{array}$ \\
\hline
\end{tabular}

aSee EPRI (2001).

Table 2. Risk factors of MSDs from cutting wire with manual tools and improvements with the battery-operated cutter

\begin{tabular}{|l|l|l|}
\hline Risk factor & Current practice risks & $\begin{array}{l}\text { Improvement with battery- } \\
\text { operated cutter }\end{array}$ \\
\hline $\begin{array}{l}\text { High upper extremity force } \\
\text { exertions to close cutter handles }\end{array}$ & $\begin{array}{l}\text { Operating a cutter is similar to operating } \\
\text { a manual press }\end{array}$ & Substantially reduced \\
\hline $\begin{array}{l}\text { Forceful lowering of arms } \\
\text { (shoulder adduction) }\end{array}$ & $\begin{array}{l}\text { High forces exerted by the upper } \\
\text { extremity and shoulders although not } \\
\text { measured }\end{array}$ & $\begin{array}{l}\text { Substantially reduced with a } \\
\text { finger pull on the trigger }\end{array}$ \\
\hline $\begin{array}{l}\text { Arms raised above shoulder } \\
\text { level (shoulder abduction) }\end{array}$ & & Substantially reduced \\
\hline
\end{tabular}




\begin{tabular}{|l|l|l|}
\hline $\begin{array}{l}\text { Jarring action from quick drop in } \\
\text { force when wire is cut }\end{array}$ & Eliminated \\
\hline $\begin{array}{l}\text { Repetitive upper extremity } \\
\text { exertions using the ratchet } \\
\text { cutter }\end{array}$ & & Eliminated \\
\hline $\begin{array}{l}\text { Twisted and awkward trunk } \\
\text { postures from bucket }\end{array}$ & & \\
\hline
\end{tabular}

\subsubsection{Alternative interventions considered}

Two alternatives to the battery-operated press were tested and reviewed. Compared to the manual compression press, a powder-activated wedge connector also reduced shoulder forces, but not to the degree that the battery-operated press did.

An alternative to the battery-operated cutter was the use of cutter blades available with the battery-operated press. Though this would save initial cost expenditures because only one tool would be required, changing the head on a battery-operated press so that it can press connectors and cut the wire required more setup time than battery-operated tools dedicated to one purpose.

\subsubsection{Current cost breakdown}

\subsubsection{Medical and workers' compensation costs}

The injuries and corresponding medical and workers compensation costs for the previous 2.5 year period (January 1999-July 2001) at the utility were analyzed because that was the length of time the current medical and workers' compensation database had been in place. Forty-seven severe cases from a list of all MSDs affecting line workers were investigated and are listed in Table 3. These 47 injuries, which resulted in LWDs or RD days, were identified by an occupational health nurse at the utility. As shown in Table 3, comprehensive medical and workers' compensation costs for these 47 MSD cases totaled $\$ 478,605$, annualized at $\$ 191,440$ or $\$ 517$ per worker. It is not known whether there were additional costs incurred.

Table 3. Utility's medical and workers' compensation costs for 47 MSD injuries that resulted in LWDs or RD days (January 1999-July 2001)

\begin{tabular}{|l|l|l|l|}
\hline Type of injury & $\begin{array}{l}\text { Total medical costs, indemnity, reimbursements } \\
\text { for drugs, parking, transportation }\end{array}$ & Annualized & $\begin{array}{l}\text { Annualized per } \\
\text { employee } \mathbf{N = 3 7 0}\end{array}$ \\
\hline $\begin{array}{l}\text { Upper extremity } \\
\text { injuries }\end{array}$ & $\$ 179,296$ & $\$ 71,718$ & $\$ 194$ \\
\hline Neck injuries & $\$ 160,573$ & $\$ 64,229$ & $\$ 174$ \\
\hline Knee injuries & $\$ 46,307$ & $\$ 18,522$ & $\$ 50$ \\
\hline Back injuries & $\$ 92,429$ & $\$ 36,971$ & $\$ 99$ \\
\hline Totals & $\$ 478,605$ & $\$ 191,440$ & $\$ 517$ \\
\hline
\end{tabular}

\subsubsection{Injury review}

All non-acute injuries affecting line workers at the utility during the past 2.5 years affecting line workers at the utility are listed in Table 4. The MSDs are categorized according to how far the injury advanced (early, mid, or late stage). Injuries listed in the late column could have been reported earlier, but they advanced to the late stage where they developed into an occupational illness; inflammation to muscles, tendons, or sheaths; or resulted in RD or LWDs. 
Table 4. All reported MSDs (January 1999-July 2001) of line workers $(n=370)$ at the utility by body part and progression of reporting

\begin{tabular}{|c|c|c|c|c|c|}
\hline $\begin{array}{l}\text { Progression by } \\
\text { reporting }\end{array}$ & & & & & \\
\hline $\begin{array}{l}\text { Body part or } \\
\text { injury type }\end{array}$ & $\begin{array}{l}\text { Early (first aid or first } \\
\text { time medical } \\
\text { treatment) }\end{array}$ & $\begin{array}{l}\text { Mid (OSHA } \\
\text { recordable } \\
\text { injuries) }\end{array}$ & $\begin{array}{l}\text { Late (occupational illness, } \\
\text { inflammation, RD and } \\
\text { LWDs) }\end{array}$ & Total & $\begin{array}{l}\% \\
\text { reported } \\
\text { late }\end{array}$ \\
\hline Non-repetitive & 11 & 5 & 1 & 17 & 3 \\
\hline Wrist & 5 & 1 & 1 & 7 & 14 \\
\hline Elbow & 4 & 8 & 2 & 14 & 14 \\
\hline Shoulder & 6 & 6 & 7 & 19 & 37 \\
\hline Upper arm & 0 & 0 & 1 & 1 & 100 \\
\hline Forearm & 1 & 1 & 1 & 3 & 33 \\
\hline Back & 25 & 12 & 20 & 57 & 35 \\
\hline Leg & 1 & 0 & 0 & 1 & 0 \\
\hline Knee & 15 & 8 & 2 & 25 & 8 \\
\hline Neck & 0 & 0 & 3 & 3 & 100 \\
\hline Inflammation & 1 & 2 & 3 & 6 & 50 \\
\hline $\begin{array}{l}\text { Carpal tunnel } \\
\text { syndrome }\end{array}$ & 0 & 2 & 3 & 5 & 60 \\
\hline $\begin{array}{l}\text { Other } \\
\text { occupational } \\
\text { illness }\end{array}$ & 0 & 1 & 1 & 2 & 50 \\
\hline $\begin{array}{l}\text { Multiple body } \\
\text { parts }\end{array}$ & 3 & 2 & 2 & 7 & 17 \\
\hline Totals & 72 & 48 & 47 & 167 & 28 \\
\hline
\end{tabular}

The bold faced numbers reflected the body parts with high number of incidences. Early and mid injuries resulted in no LWDs or RD days; late injuries resulted in RD or LWDs or were relatively severe, such as those requiring surgery.

The MSDs listed in Table 4 represented all the non-acute injuries reported to the company by the population of 370 line workers at the utility. Of the 167 injuries, 25 or $15 \%$ of the total were to workers with more than one reported injury. When one considers that approximately $1 / 3$ of all 370 line workers were apprentices who would not likely be reporting an MSD but more likely a traumatic injury, this meant that more than half of the experienced line workers were reporting an injury (167 injuries minus 25 multiple injuries equals 142 line workers reporting injuries; 142 line worker injuries divided by 248 non-apprentice line workers exceeded $50 \%$.)

A thorough review of the injuries in Table 4 revealed that $73 \%$ of the RD or LWD cases (34 of the 47 severe injuries) had not been previously reported within the utility, while 13 of the 47 severe cases had already been tracked. Early and mid reported injuries were those which did not result in RD or LWDs, as well as a few odd injuries defined as occupational illness or inflammation of the joints, muscles, and tendons. The corporate ergonomist conducted a thorough investigation of all records, which elicited the 34 previously unreported cases that resulted in RD or LWDs.

The costs of treating injuries early in the disease process were less expensive than treating them later as illustrated in Table 5. For shoulder injuries, the early cost of treating tendonitis was $\$ 4500$ at the utility, which contrasted with extensive treatment costs from $\$ 17,000$ to $\$ 71,000$ for treatment at an advanced stage. For 
back injuries, typical chiropractic cost $\$ 775$ (1989 figures) and medical costs of $\$ 1665$ per case were substantially less than the surgical costs of $\$ 24,000$ (Jarvis, 1991). These data illustrated that through early reporting of injuries and implementation of ergonomic interventions, excessive medical costs could possibly be reduced.

Table 5. Average medical, workers' compensation (WC), and disability costs for 47 injuries listed in Table 3

\begin{tabular}{|l|l|l|l|}
\hline Injury/treatment & $\begin{array}{l}\text { Med/WC costs } \\
\text { (averages) }\end{array}$ & $\begin{array}{l}\text { Permanent partial } \\
\text { disability (single cases) }\end{array}$ & $\begin{array}{l}\text { Classification of } \\
\text { how early treated }\end{array}$ \\
\hline $\begin{array}{l}\text { Injuries which did not result in RD or } \\
\text { LWDs }\end{array}$ & & & \\
\hline Shoulder Tendinitis & $\$ 4500$ & $5 \%-\$ 4600$ & Mid-late \\
\hline Elbow (Epicondylitis) & $\$ 3100$ & & Mid \\
\hline Injuries which resulted in RD or LWDs & & & \\
\hline Back surgery & $\$ 24000$ & & Late \\
\hline Shoulder replacement & $\$ 71000$ & & Late \\
\hline Rotator cuff & $\$ 17000$ & & Late \\
\hline Carpal tunnel syndrome & $\$ 8200$ & $10 \%-\$ 7820$ & Late \\
\hline Knee & $\$ 23153$ & Late \\
\hline
\end{tabular}

\subsubsection{Cost averages per injury type}

The average costs of the 47 severe injuries from Table 3 whose medical and workers' compensation data were tracked within the company are listed in Table 5 according to injury and treatment. For the purposes of this business case, the upper extremity MSD cases were representative of those injuries that could either be reduced in severity or possibly prevented by the purchase of the battery-operated press and cutter. The lower back or knee injuries were theorized to not be substantially impacted by the implementation of the battery-operated press and cutter.

\subsubsection{Retraining and replacement costs}

Information provided by the human resources and distribution operations departments at the utility detailed the costs associated with replacing an injured worker. There were generally three kinds of replacement workers:

-Short term-1-8 weeks while worker was recovering and may be on light duty, if such work was available. The replacement worker must be ready to work when called, which meant the replacement worker was a trained and skilled line worker.

-Long term-2-12 months. The replacement worker must be a trained and skilled line worker.

-Permanent-injured worker left or was 'fitted' into another job in the company due to disability. The replacement worker was an apprentice who began at the bottom, who was less productive than the workers with more experience, and required substantial training and mentoring for the first few years on the job.

Costs were calculated for replacing skilled line workers who were out on RD or LWDs with line workers who had sufficient training and skills to perform at the level of the replaced skilled worker. Training costs of apprentices were calculated for skilled workers who must leave their jobs permanently.

Many line workers did not have the physical capability to stay on the job for their entire working life. Only $10 \%$ of the apprentices currently hired at the utility were replacing retirees, which meant that the utility spent a 
considerable amount of money and time on replacing non-retired line workers in order to maintain their employment base of 370 line workers.

All of the severe MSD cases investigated at the host utility required long term or permanent replacement of skilled line workers. Many of the replacement workers must be already trained and skilled since in many cases there was already an apprentice on a typical three-person crew. The training program for apprentices at the utility had three components, listed below in chronological order.

-Weekend crash course consisting of climbing electric poles and introduction to the hazards of the job12-24 $\mathrm{h}$ (depending on whether the applicant is external or internal) at $\$ 19 / \mathrm{h}$ (wages); $\$ 228-456$ per trainee.

-A few candidates dropped out in first 2 weeks due to fear of heights or physical demands (averaging three dropouts per year) at a cost of $\$ 1500$ per trainee.

-Apprenticeship program of 3 years -60 days $\times 8 \mathrm{~h}=480 \mathrm{~h}$ at $\$ 27 / \mathrm{h}$ (wages and benefits) $=\$ 13,000$ per apprentice; 10 people per class, classes met 3-4 times/year. These costs were only for the training portion of that 3-year period, not wages and benefits while the apprentice was working on a crew. Since the training period spans 3 years, the utility had approximately 105 first, second, and third year apprentices in training during any given year.

-Productivity losses for the use of apprentices, since most utilities have work rules requiring a lead or highly skilled line worker to be on the job with an apprentice.

-When skilled workers go on restricted or light duty, they did not perform their regular jobs.

- Clerical/processing costs per replacement worker: $\$ 300 /$ worker minimum.

-Specific company/union agreements for placing workers with extensive injuries. For example, after 15 or more years of service, if a line worker were determined as a result of cumulative work exposure to be medically unable to perform job requirements of line work, he could sometimes move into a less physically demanding job. Sometimes, he was paid a differential closer to higher line worker pay, depending on years of service. The utility had four workers who were formally moved into less physically demanding jobs in the last few years, but many others either left the company or took supervisory positions.

The costs of replacing 43 of the 47 workers who incurred injuries resulting in restricted or LWDs from Table 4 are shown in Table 6. There were insufficient data available for four cases at the time of publication. The annualized cost per line worker for replacing skilled injured workers was categorized according to upper extremity and back in Table 7.

Table 6. Restricted duty (RD) days and lost workdays (LWDs) of MSDs requiring full time replacement workers categorized by all body parts and injury types (total number of RD and LWD cases with full data was 43; four of the 47 did not have full data) (January 1999-July 2001)

\begin{tabular}{|l|l|l|l|l|l|l|l|}
\hline $\begin{array}{l}\text { Body } \\
\text { part/injury }\end{array}$ & $\begin{array}{l}\text { \# of } \\
\text { RD } \\
\text { cases }\end{array}$ & $\begin{array}{l}\text { \# of } \\
\text { RD } \\
\text { days }\end{array}$ & $\begin{array}{l}\text { \# of } \\
\text { LWD } \\
\text { cases }\end{array}$ & $\begin{array}{l}\text { \# of } \\
\text { LW } \\
\text { days }\end{array}$ & $\begin{array}{l}\text { Totals } \\
\text { RD/LW } \\
\text { days } \\
\text { missed }\end{array}$ & $\begin{array}{l}\text { Replacement worker } \\
\text { costs totals (skilled } \\
\text { worker at } \mathbf{3 6 / h )}\end{array}$ & $\begin{array}{l}\text { Annualized per } \\
\text { line worker } \\
\text { (n=370) }\end{array}$ \\
\hline Shoulder & 7 & 185 & & & 185 & $\$ 56,448$ & $\$ 61$ \\
\hline Back & 17 & 407 & 3 & 90 & 497 & $\$ 143,136$ & $\$ 155$ \\
\hline Knee & 1 & 90 & 1 & 43 & 133 & $\$ 51,552$ & $\$ 56$ \\
\hline Elbow & 2 & 2 & & & 2 & $\$ 576$ & $\$ 1$ \\
\hline Inflammation & 3 & 60 & & & 60 & $\$ 17,280$ & $\$ 19$ \\
\hline
\end{tabular}




\begin{tabular}{|l|l|l|l|l|l|l|l|}
\hline $\begin{array}{l}\text { Carpal tunnel } \\
\text { syndrome }\end{array}$ & 1 & 14 & 2 & 41 & 55 & $\$ 15,840$ & $\$ 17$ \\
\hline $\begin{array}{l}\text { Occupational } \\
\text { illness }\end{array}$ & 1 & 56 & & & 56 & $\$ 16,128$ & $\$ 17$ \\
\hline $\begin{array}{l}\text { Multiple body } \\
\text { parts }\end{array}$ & 1 & 20 & 1 & 11 & 31 & $\$ 5760$ & $\$ 6$ \\
\hline Wrist & 1 & 3 & & & 3 & $\$ 864$ & $\$ 1$ \\
\hline Upper arm & 1 & 2 & & & 2 & $\$ 576$ & $\$ 1$ \\
\hline Forearm & 1 & 46 & & & 46 & $\$ 0$ & $\$ 0$ \\
\hline Totals & 36 & 885 & 7 & 185 & 1070 & $\$ 308,160$ & 334 \\
\hline
\end{tabular}

aAt the utility, line workers on RD go home, so the replacement and productivity costs are the same for RD as for LWDs.

Table 7. Average restricted duty (RD) days and lost workdays (LWDs) of MSDs requiring full time replacement workers categorized by upper extremity and back (January 1999-July 2001)

\begin{tabular}{|l|l|l|l|l|l|l|l|}
\hline $\begin{array}{l}\text { Body } \\
\text { part/injury }\end{array}$ & $\begin{array}{l}\text { \# of } \\
\text { RD } \\
\text { cases }\end{array}$ & $\begin{array}{l}\text { \# of } \\
\text { RD } \\
\text { days }\end{array}$ & $\begin{array}{l}\text { \# of } \\
\text { LWD } \\
\text { cases }\end{array}$ & $\begin{array}{l}\text { \# of } \\
\text { LW } \\
\text { days }\end{array}$ & $\begin{array}{l}\text { Totals } \\
\text { RD/LW } \\
\text { days } \\
\text { missed }\end{array}$ & $\begin{array}{l}\text { Replacement worker } \\
\text { costs totals } \text { (skilled } \\
\text { worker at } \$ 36 / h)\end{array}$ & $\begin{array}{l}\text { Annualized per } \\
\text { line worker } \\
\text { (n=370) }\end{array}$ \\
\hline $\begin{array}{l}\text { Upper } \\
\text { extremity and } \\
\text { neck only }\end{array}$ & 18 & 388 & 3 & 52 & 440 & $\$ 126,720$ & $\$ 137$ \\
\hline Back only & 17 & 407 & 3 & 90 & 497 & $\$ 143,136$ & $\$ 155$ \\
\hline
\end{tabular}

aAt the utility, line workers on RD are sent home.

bThough there were three cases of severe neck injuries with substantial medical and workers' compensation costs, the medical database did not clearly show if there were RD or LWDs associated with them. The data were either never updated to show the RD or LW days or the workers took sick leave.

\subsubsection{Cost authorization needed}

The battery-operated press cost approximately $\$ 2000$ and the battery-operated cutter approximately $\$ 1000$, which summed to $\$ 3000$ per crew of three line workers or $\$ 1000$ per worker in a three-person crew. The battery-operated tools were expected to last 5 years, resulting in a cost of $\$ 200$ per line worker per year. The total initial cost of providing each of the approximately 100 overhead distribution line worker crews at the utility one battery-operated press and one battery-operated cutter was $\$ 300,000$.

\subsubsection{Simplified cost-benefit methodology}

All of the benefit and cost data are summarized in Table 8. Assumptions are listed for each specific cost. Based on substantial reduction of MSD risk factors from the battery-operated tools as shown in Table 9, the authors assumed the battery-operated press and cutter would reduce the medical and workers' compensation costs of the upper extremity MSDs by 50\% and that four additional cases would be either managed at an early stage or prevented by implementation of the battery-operated tools. The projected savings in medical and workers' compensation cost indicated in Table 9 were projected to be a conservative estimate of the actual savings in this category due to reduction of late reporting of injuries.

Table 8. Summary of projected savings from replacing manual tools with battery-operated tools

\begin{tabular}{|l|l|l|l|}
\hline & Assumptions & $\begin{array}{l}\text { Projected annual } \\
\text { total savings by }\end{array}$ & $\begin{array}{l}\text { Projected } \\
\text { annual total }\end{array}$ \\
\hline
\end{tabular}




\begin{tabular}{|l|l|l|l|}
\hline & \multicolumn{1}{|l|}{$\begin{array}{l}\text { purchase of } \\
\text { battery tools }\end{array}$} & $\begin{array}{l}\text { savings per line } \\
\text { worker }(\boldsymbol{n}=\mathbf{3 7 0})\end{array}$ \\
\hline $\begin{array}{l}\text { Medical and WC } \\
\text { extremity only }\end{array}$ & $\begin{array}{l}\text { 50\% reduction from 25 severe MSD cases of } \\
\text { the upper extremities (and neck) using } \\
\text { manual tools to } 12 \text { severe cases using battery } \\
\text { tools; 8\% cost increase regardless }\end{array}$ & $\$ 73,411$ & $\$ 198$ \\
\hline $\begin{array}{l}\text { Replacement } \\
\text { workers }\end{array}$ & $\begin{array}{l}50 \% \text { reduction from 440 (176 annual) RD and } \\
\text { LWD days at \$36/h, wages and benefits for } \\
\text { skilled worker }\end{array}$ & $\$ 25,344$ & $\$ 68$ \\
\hline Retraining & $\begin{array}{l}10 \% \text { reduction due to upper extremity } \\
\text { improvement in \# of new apprentices who } \\
\text { replace non-retiring line workers; reduction } \\
\text { of 10 over 3 years, annual cost of \$4333 from } \\
\text { the \$13,000 3 year cost per apprentice }\end{array}$ & $\$ 45,500$ & $\$ 123$ \\
\hline $\begin{array}{l}\text { Costs of upper } \\
\text { extremity late } \\
\text { reporting and severe } \\
\text { progression }\end{array}$ & $\begin{array}{l}\text { Reduction of medical costs for two cases of } \\
\text { non-reported or late reported injuries }\end{array}$ & $\$ 40,000$ & $\$ 108$ \\
\hline Totals & & & \\
\hline
\end{tabular}

Table 9. Summary of payback period of purchasing 100 sets of battery-operated presses and cutters compared to costs of making connections and cuts with manual tools

\begin{tabular}{|l|l|l|l|l|l|l|}
\hline $\begin{array}{l}\text { Product } \\
\text { type }\end{array}$ & $\begin{array}{l}\text { Estimated } \\
\text { total annual } \\
\text { benefit }\end{array}$ & $\begin{array}{l}\text { Annual } \\
\text { benefit per } \\
\text { line worker } \\
(\boldsymbol{n}=\mathbf{3 7 0})\end{array}$ & $\begin{array}{l}\text { Estimated total } \\
\text { annual cost of } \\
\text { battery press and } \\
\text { cutter per line } \\
\text { worker }(\boldsymbol{n}=\mathbf{3 7 0})\end{array}$ & $\begin{array}{l}\text { Estimated } \\
\text { annual cost }\end{array}$ & $\begin{array}{l}\text { Estimated total } \\
\text { cost of } \\
\text { purchasing } 100 \\
\text { sets of battery } \\
\text { tools }\end{array}$ & $\begin{array}{l}\text { Payback } \\
\text { in years }\end{array}$ \\
\hline $\begin{array}{l}\text { Battery- } \\
\text { operated } \\
\text { press }\end{array}$ & $\times$ & $\times$ & $\$ 133$ & $\$ 40,000$ & $\$ 200,000$ & \\
\hline $\begin{array}{l}\text { Battery- } \\
\text { operated } \\
\text { cutter }\end{array}$ & $\times$ & $\times$ & $\$ 67$ & $\$ 20,000$ & $\$ 100,000$ & \\
\hline \begin{tabular}{l} 
Totals \\
\hline 184,255
\end{tabular} & $\$ 498$ & $\$ 200$ & $\$ 60,000$ & $\$ 300,000$ & $\begin{array}{l}4 \\
\text { months }\end{array}$ \\
\hline
\end{tabular}

$\mathrm{a}(\$ 60,000 / \$ 184,255) \times 12$ months.

A step-by step breakdown of the methodology used to interpret the cost and benefit data available at the utility was formulated. It is important to note that the benefit assumptions were conservative projections of the authors, based upon the severity of the ergonomic risk factors associated with the current use of manual tools and the laboratory studies of the force reductions which battery-operated tools provided.

The following are the benefit assumptions and methodology of the calculations of benefits in Table 8:

- Medical and workers compensation cost-benefit was calculated by

(1) $B_{1}=(1.08 \times 135,947) / 2=\$ 73,411$,

where $B_{1}$ was the projected annual benefit of $\$ 73,411$, and $\$ 135,947$ was the annual medical and workers compensation cost for upper extremity and neck reported injuries from Table 3 . An $8 \%$ increase in these costs 
due to medical insurance premium increases was projected since these premiums have increased $8.3 \%$ nationally in 1999-2000 (Landers, 2000). The 25 cases selected from the severe injuries excluded back, leg, and knee injuries which would not be positively impacted in a significant way by the new battery tools (refer to Table 4). A projection of a $1 / 2$ reduction in the severe injuries - those resulting in lost work time and/or surgery-was considered to be a conservative estimate, since the use of these tools basically exceeds the strength capabilities of $99 \%$ of the general population and that the personnel data indicated few able to avoid upper extremity injuries due to their use after several years of exposure.

- Replacement workers costs were calculated by

(2) $B_{2}=(440 / 2.5)(36 \times 8) / 2=\$ 25,344$,

where $B_{2}$ was the annual cost of $\$ 25,344$ in wages and benefits for replacement workers of injured workers reporting work-related injuries, 440 was the number of days missed for RD or LWDs injuries of the upper extremities and neck divided by 2.5 years (the database time period), and $\$ 36.00$ per hour was the average rate of pay plus benefits multiplied by an 8 hour day (refer to Table 7). There were actually no neck RD or LW days reported at the time of publication. Overtime-extensive for these workers during storm outages-was not considered. The entire cost for these injuries was divided in half under the conservative assumption that the improvement in strength capability from $1 \%$ to virtually $100 \%$ of the general population would result in the greatest occupational health benefit of all the interventions considered.

- Reduction in retraining costs for new apprentices were calculated as

(3) $B_{3}=[(13,000 \times 105) / 3] / 10=\$ 45,500$,

where $B_{3}$ was the annual projected reduction in the training costs for new apprentices at a cost of $\$ 13,000$ each for 105 apprentices (35/year) over 3 years. A conservative reduction of only $10 \%$ fewer apprentices was forecast, even though $90 \%$ of the new apprentices replace workers with long-term injuries, while only $10 \%$ replace retirees. The utility also hired replacement workers from other utilities and those trained in technical college programs who did not require an apprenticeship program. These costs were directly tied to LWDs and RD days for line workers, since an apprentice could not replace a skilled worker.

- Reduction in costs of upper extremity late reporting were calculated in

(4) $B_{4}=20,000 \times 2=\$ 40,000$,

where $B_{4}$ was the projected average benefit of the reduction in labor and medical costs for injuries that go unreported and were not medically managed until the injury became so severe that surgery or extended missed work time would be required. This was estimated to be an average of $\$ 20,000$ per case, and a reduction of two cases per year. Since $73 \%$ of the 47 severe injuries fall into this category (refer to Table 4), a reduction of two injuries is an extremely conservative figure. Utilities paid for the medical insurance premiums, sick and vacation days even when injuries were unreported. Line workers often worked in spite of injuries but were likely to be less productive when hurt.

\subsubsection{Product type}

The battery-operated press and cutter was considered a capital expenditure in the utility.

\subsubsection{Annual benefit}

The total projected savings from supplying each of the 100 overhead distribution line crews with the batteryoperated were calculated according to

(5) $B=\left(B_{1}+B_{2}+B_{3}+B_{4}\right) / 370=\$ 184,255$, 
where $B_{1}$ was the annual medical and workers compensation savings, $B_{2}$ was the annual replacement workers savings, $B_{3}$ was the annual apprentice training savings, $B_{4}$ was the annual late reporting savings. The total annual savings from purchasing the two battery-operated tools was $\$ 184,255$ or $\$ 498$ per line worker per year, as shown in Table 9.

\subsubsection{Estimated total cost}

Across 100 crews at $\$ 3000$ per crew $-\$ 2000$ for the battery press, $\$ 1000$ for the battery cutter - the estimated total initial cost for the battery-operated presses and cutters was $\$ 300,000$, with replacements forecast at 5 year periods. Industry contacts indicated that many of these tools have a useful life of 8-10 years.

\subsubsection{Payback period}

According to the benefit and cost data summarized in Table 9, the capitalized payback period for supplying each of the 100 overhead distribution line crews with a battery-operated press and cutter was 4 months.

\subsubsection{Request for approval}

The ergonomics team assembled and reviewed evaluation data from a pilot study in which several work crews used the battery-operated press and cutters. In addition, the team reviewed results of its search and investigation of new battery-operated tools on the market. Furthermore, the team evaluated results from a musculoskeletal survey administered to the line workers on the three crews. The team tracked all implementation issues with the appropriate safety team and business unit safety committee. Based on feedback from the pilot study, the team requested $\$ 300,000$ from the utility to outfit all of its 100 overhead distribution crews with battery-operated tools.

\section{Discussion of business case}

The business case model for justifying ergonomic interventions presented in this manuscript had limitations, which are chiefly estimating costs and savings. The costs of medical treatment of MSDs and replacement workers were not known exactly, and likewise the projected savings from implementing the battery-operated tools on medical, workers' compensation, and hiring fewer replacement workers were not known. Gathering requisite data for assembling a benefit/cost argument for ergonomic interventions was a difficult task, and the corporate ergonomist at the utility worked at least 3 months investigating injury cases to track down the actual costs. Although the data presented in this business case were estimates, they are believed to be as accurate as possible and conservative in nature. Based on the assumptions of the model and the data collected at the utility, the capitalized payback period of 4 months made a compelling case for incorporating battery-operated presses and cutters into the work practices of overhead distribution line workers. The utility committed over $\$ 300,000$ to purchase battery-operated presses and cutters for their overhead distribution line crews.

\section{Conclusions}

The payback period for ergonomic interventions was demonstrated to be surprisingly short when the relevant data were collected and interpreted. Health and safety professionals have struggled for years making the case for capital investment of tools that would reduce the magnitude of MSD risk factors. Properly documented and packaged, a sound business case could sell itself and aid ergonomists and health professionals in their efforts to improve the occupational health of workers.

\section{Acknowledgements}

This study was financially supported by Research Contract \#7318-01 from EPRI (Electric Power Research Institute), 3412 Hillview Avenue, Palo Alto, CA. The authors are grateful to Dr. Janice Yager from EPRI for her 
technical leadership and also to the manufacturers who supplied the ergonomics team at the utility with tools and equipment for evaluation.

\section{References}

Boff and Rouse's (1997). Boff, K.R., Rouse, W.B., 1997. Assessing Cost/Benefits of Human Factors. In: Handbook of Human Factors and Ergonomics, 2nd Edition. Gavriel Salvendy, Wiley, New York, pp. 1617-1633.

Electric Power Research Institute (EPRI), (2001). Electric Power Research Institute (EPRI), 2001. Final report for ergonomics handbook for the electric power industry: overhead distribution line workers interventions. EPRI Report Number 1005199, EPRI, Palo Alto, CA.

Ergonomics That Work, (1998). Ergonomics That Work, 1998. LRP Publications, Palm Beach Gardens, FL.

Jarvis (1991). Jarvis, K.B., et al., 1991. Cost per case comparison of back injury claims of chiropractic versus medical management for conditions with identical diagnostic codes. Journal of Occupational Medicine $33,847-852$.

Landers (2000). Landers, S., 2000. Employers Absorbing Insurance Cost Hikes. American Medical News, October 2.

Rodrigues (2001). C.C. Rodrigues. Ergonomics to the rescue: a cost justification case study. Professional Safety, 45 (4) (2001), pp. 32-34

Slavin (2001). Slavin, T., 2001. MSD's and total employee productivity: an industrial view. Presentation at the Human Factors and Ergonomics Society 45th Annual Meeting, Minneapolis, MN, October 11. 